In cooperation with the United States Environmental Protection Agency, States, and Tribes

\title{
Total Cylindrospermopsins, Microcystins/Nodularins, and Saxitoxins Data for the 2007 United States Environmental Protection Agency National Lake Assessment
}

Data Series 929

U.S. Department of the Interior

U.S. Geological Survey 
Front cover. East Okoboji Lake in lowa, August 9, 2006.

Back cover. Smithville Lake in Missouri, August 11, 2006.

Photographs by Jennifer L. Graham, U.S. Geological Survey. 


\section{Total Cylindrospermopsins, Microcystins/ Nodularins, and Saxitoxins Data for the 2007 United States Environmental Protection Agency National Lake Assessment}

By Keith A. Loftin, Julie E. Dietze, Michael T. Meyer, Jennifer L. Graham, Megan M. Maksimowicz, and Kathryn D. Toyne

In cooperation with the United States Environmental Protection Agency, States, and Tribes

Data Series 929 


\title{
U.S. Department of the Interior SALLY JEWELL, Secretary
}

\section{U.S. Geological Survey Suzette M. Kimball, Director}

\author{
U.S. Geological Survey, Reston, Virginia: 2016
}

For more information on the USGS - the Federal source for science about the Earth, its natural and living resources, natural hazards, and the environment—visit http://www.usgs.gov or call 1-888-ASK-USGS.

For an overview of USGS information products, including maps, imagery, and publications, visit http://store.usgs.gov.

Any use of trade, firm, or product names is for descriptive purposes only and does not imply endorsement by the U.S. Government.

Although this information product, for the most part, is in the public domain, it also may contain copyrighted materials as noted in the text. Permission to reproduce copyrighted items must be secured from the copyright owner.

Suggested citation:

Loftin, K.A., Dietze, J.E, Meyer, M.T., Graham, J.L, Maksimowicz, M.M., and Toyne, K.D., 2016, Total cylindrospermopsins, microcystins/nodularins, and saxitoxins data for the 2007 United States Environmental Protection Agency National Lake Assessment: U.S. Geological Survey Data Series 929, 9 p., http://dx.doi.org/10.3133/ds929. 


\section{Acknowledgments}

Support for this work was provided by several sources and includes the following: U.S. Environmental Protection Agency Office of Wetlands, Oceans and Watersheds, (Sarah Lehman, Project Officer, IA\# DW1492215401); U.S. Environmental Protection Agency Office of Research and Development National Health and Environmental Effects Research Laboratory (Elizabeth Hilborn, Project Officer, IA\# DW14958073). The authors gratefully acknowledge Elizabeth Hilborn (U.S. Environmental Protection Agency Office of Research and Development National Health and Environmental Effects Research Laboratory) for her helpful review comments.

Support was also provided by the U.S. Geological Survey's Area Strategic Integrated Science and Technology Funds South Central Area; National Water Quality Assessment Program; and the Toxic Substances Hydrology Program. The authors greatfully acknowledge Donna Francy (U.S. Geological Survey Ohio Water Science Center), Ted Harris (USGS Kansas Water Science Center) for their helpful review comments. 


\section{Contents}

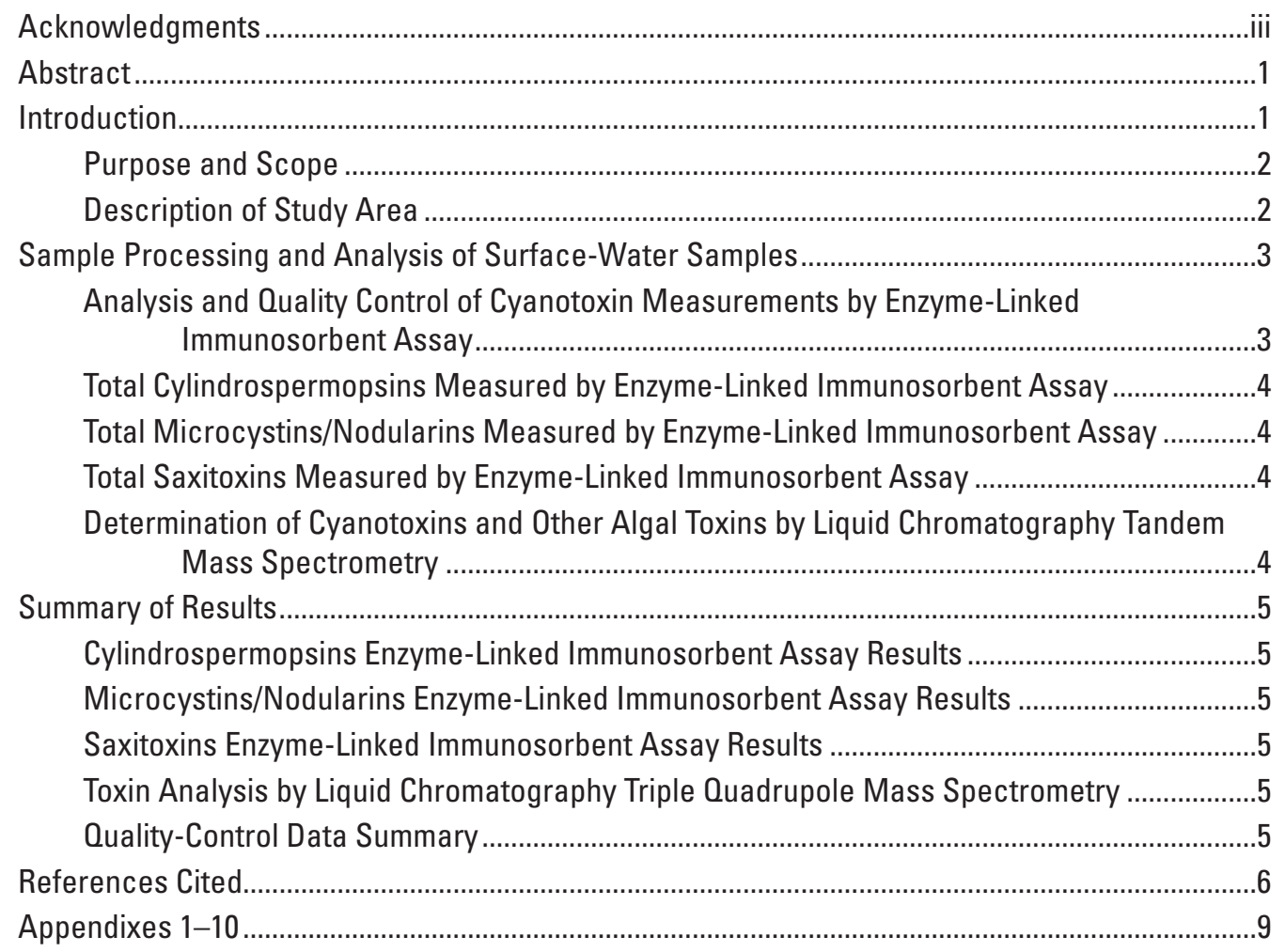

\section{Tables}

1. Provisional World Health Organization recreational guidelines for microcystin-LR, cyanobacterial abundance, and chlorophyll-a in surface waters ....................................

2. Summary of samples analyzed by enzyme-linked immunosorbent assay ..........................3 


\title{
Conversion Factors
}

International System of Units to Inch/Pound

\begin{tabular}{|c|c|c|}
\hline Multiply & By & To obtain \\
\hline \multicolumn{3}{|c|}{ Length } \\
\hline micrometer $(\mu \mathrm{m})$ & $3.937 \times 10^{-5}$ & inch (in.) \\
\hline millimeter (mm) & 0.03937 & inch (in.) \\
\hline kilometer (km) & 0.6214 & mile (mi) \\
\hline \multicolumn{3}{|c|}{ Area } \\
\hline square meter $\left(\mathrm{m}^{2}\right)$ & 0.0002471 & acre \\
\hline hectare (ha) & 2.471 & acre \\
\hline \multicolumn{3}{|c|}{ Volume } \\
\hline liter $(\mathrm{L})$ & 0.2642 & gallon (gal) \\
\hline milliliter (mL) & $2.642 \times 10^{-4}$ & gallon (gal) \\
\hline microliter $(\mu \mathrm{L})$ & $2.642 \times 10^{-7}$ & gallon (gal) \\
\hline \multicolumn{3}{|c|}{ Concentration } \\
\hline microgram per milliliter $(\mu \mathrm{g} / \mathrm{mL})$ & 1.0 & part per million (ppm) \\
\hline microgram per Liter $(\mu \mathrm{g} / \mathrm{L})$ & 1.0 & part per billion (ppb) \\
\hline
\end{tabular}

\section{Supplemental Information}

Temperature in degrees Celsius $\left({ }^{\circ} \mathrm{C}\right)$ may be converted to degrees Fahrenheit $\left({ }^{\circ} \mathrm{F}\right)$ as follows:

${ }^{\circ} \mathrm{F}=\left(1.8 x^{\circ} \mathrm{C}\right)+32$

Temperature in degrees Fahrenheit $\left({ }^{\circ} \mathrm{F}\right)$ may be converted to degrees Celsius $\left({ }^{\circ} \mathrm{C}\right)$ as follows:

${ }^{\circ} \mathrm{C}=\left({ }^{\circ} \mathrm{F}-32\right) / 1.8$

\section{Abbreviated Water-Quality Units}

\author{
g gram \\ $\mu \mathrm{g} / \mathrm{L} \quad$ microgram per liter \\ $\mu \mathrm{g} / \mathrm{mL} \quad$ microgram per milliliter \\ $\mu \mathrm{L} / \mathrm{min} \quad$ microliter per minute \\ $\mathrm{mg} / \mathrm{mL} \quad$ milligram per milliliter \\ $\mathrm{mL} \quad$ milliliter \\ $\mathrm{mL} / \mathrm{min} \quad$ milliliter per minute \\ cells/mL cells per milliliter
}




\section{Other Abbreviations Used in This Report}

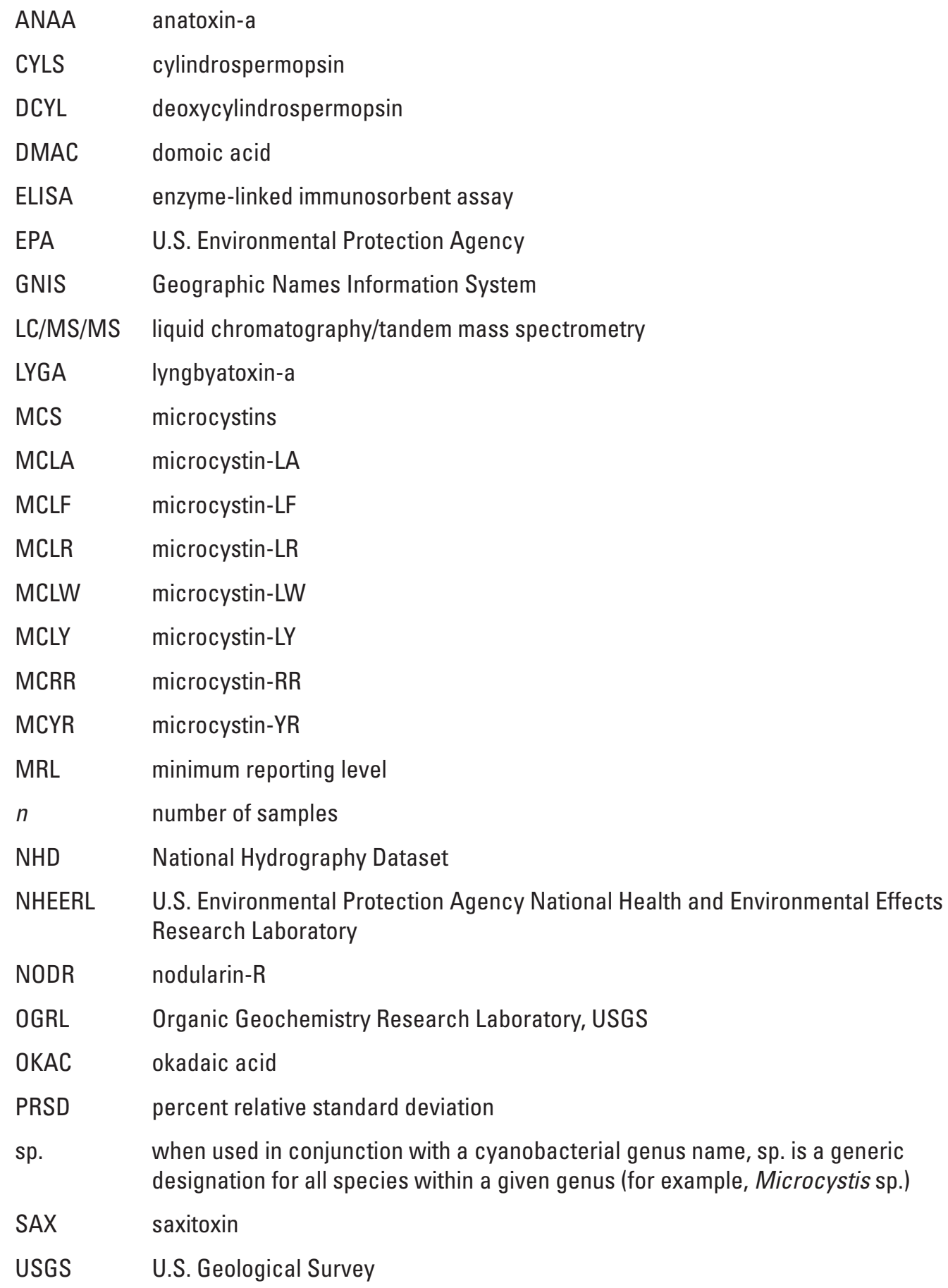




\title{
Total Cylindrospermopsins, Microcystins/Nodularins, and Saxitoxins Data for the 2007 United States Environmental Protection Agency National Lake Assessment
}

\author{
By Keith A. Loftin, Julie E. Dietze, Michael T. Meyer, Jennifer L. Graham, Megan M. Maksimowicz, and \\ Kathryn D. Toyne
}

\section{Abstract}

Phytoplankton communities in freshwater lakes, ponds, and reservoirs may be dominated by cyanobacteria (also called blue-green algae) under certain environmental conditions. Cyanobacteria may cause a range of water-quality impairments, including the potential for toxin production. Cyanobacteria toxins (cyanotoxins) may adversely impact human and ecological health. Microcystins are considered to be one of the most commonly found classes of cyanotoxins in freshwater ecosystems, and as such were selected as a recreational indicator of water quality for the 2007 United States Environmental Protection Agency (EPA) National Lakes Assessment. However, much less is known about the occurrence of other classes of cyanotoxins in fresh surface water such as anatoxins, cylindrospermopsins, nodularins, and saxitoxins.

The 2007 National Lakes Assessment followed a probabilistic study design and was directed by the EPA, in partnership with States, Tribes, and other federal agencies of the United States, to provide an assessment of water quality in the Nation's lakes, ponds, and reservoirs based on trophic status, and ecological and recreational indicators. Integrated photic zone samples were collected by the EPA, U.S. Geological Survey (USGS), States, and Tribes in target water bodies, generally at their deepest point, and analyzed for microcystins by the U.S. Geological Survey. The USGS assisted with this survey by providing technical expertise and enzyme linked immunosorbent assay (ELISA) analysis of microcystins for all survey samples as an indicator for recreational water quality. A small subset of samples $(n=27)$ was analyzed by liquid chromatography tandem mass spectrometry (LC/MS/MS) by the USGS. Additionally, through partnership with the EPA National Health and Environmental Effects Research Laboratory (NHEERL), USGS analyzed all frozen samples by ELISA for two other classes of cyanotoxins, cylindrospermopsins and saxitoxins. Total cylindrospermopsins, microcystins, and saxitoxins were measured by enzyme-linked immunosorbent assay in a total of 1,331 samples from 1,161 lakes.
Samples from this study had detection frequencies of 4.0, 32 (unweighted), and 7.7 percent, mean concentrations (detections only) of $0.56,3.0$, and 0.061 micrograms $/ \mathrm{L}(\mu \mathrm{g} / \mathrm{L})$, and maximum concentrations of 4.4, 230, and $0.38 \mu \mathrm{g} / \mathrm{L}$ for cylindrospermopsins, microcystins, and saxitoxins by ELISA, respectively in visit 1 and visit 2 samples. Microcystin ELISA results were categorized based on World Health Organization recreational surface-water guidelines for the relative probability of adverse health impacts because of microcystin exposure. The dataset described in this report is the first ever national reconnaissance of cyanotoxins in the United States.

At least one microcystin congener was detected by LC/MS/MS in 52 percent of the 27 samples analyzed at a concentration greater than the LC/MS/MS minimum reporting level (MRL) of $0.010 \mu \mathrm{g} / \mathrm{L}$ and included detections for microcystin-LA, microcystin-LR, microcystin-LY, microcystin-RR, and microcystin-YR. Anatoxin-a, cylindrospermopsin, and nodularin-R were detected in 15 percent, 7 percent, and 4 percent of samples, respectively, at concentrations above $0.010 \mu \mathrm{g} / \mathrm{L}$. Deoxycylindrospermopsin, domoic acid, lyngbyatoxin-a, microcystin-LF, microcystin-LW, and okadaic acid were not detected in the LC/MS/MS subset.

\section{Introduction}

Section 305b of the Clean Water Act (86 Stat. 816) requires the United States Environmental Protection Agency (EPA), in partnership with the States and Tribes, to provide an assessment of water quality in the United States. Review of previous National Water-Quality Inventories (U.S. General Accounting Office, 2000) revealed that, because data were "inconsistent and lacking", the EPA, States, and Tribes were not able to make statistically valid inferences about the condition of the Nation's waters or fully support management decisions to preserve and improve the Nation's water quality. In response to these critiques, the EPA began a monitoring 
program, which includes the National Aquatic Resource Surveys. One component of these surveys is a probabilistic lake, pond, and reservoir (herein referred to collectively as "lakes") survey to assess the water quality of the Nation's lakes as a function of trophic status and ecological and recreational indicators (U.S. Environmental Protection Agency, 2006, 2009a).

A variety of chemical, physical, and biological variables were measured and integrated in the 2007 National Lake Assessment (NLA) to make statistical inferences regarding surface-water quality of lakes in the United States (U.S. Environmental Protection Agency, 2007). Some of these variables, such as cyanobacteria abundance, can be directly responsible for water-quality impairments including dissolved oxygen reduction and cyanotoxin production (Chorus and Bartram, 1999; Graham and others, 2008). Microcystins, a class of hepatotoxins produced by some cyanobacteria, are currently (2013) considered to be the most commonly found cyanotoxins in freshwater systems (Chorus and Bartram, 1999; Merel and others, 2013). Microcystins are known to cause acute toxicosis in humans and other terrestrial and aquatic organisms (Chorus and Bartram, 1999; Graham and others, 2008). The World Health Organization has developed provisional recreational guidelines in freshwater systems for microcystin-LR, a commonly measured congener in the microcystin class of toxins, cyanobacterial abundance, and chlorophyll- $a$ concentrations (table 1) meant to be protective of human health (Chorus and Bartram, 1999). Congeners are chemically similar compounds with substitutions to the core structure. In the case of microcystins, most congeners are structurally the same except for two amino acids. Much less is known about the occurrence and distribution of other classes of cyanotoxins such as cylindrospermopsins and saxitoxins in the United States. However, cylindrospermopsins and saxitoxins have been reported to have toxicity of relevance to human and ecological health (Chorus and Bartram, 1999; Mazmouz and others, 2010; Etheridge and others, 2010; de la Cruz and others, 2013).

\section{Purpose and Scope}

The purpose of this non-interpretative data report is to publish the cylindrospermopsin, microcystin, and saxitoxin results from the 2007 NLA and associated quality-control data measured in 1,331 surface water samples collected during May through October 2007. Approximately 2 percent of samples $(n=27)$ were verified LC/MS/MS.

\section{Description of Study Area}

The study area included the 48 contiguous states plus Alaska (a pilot program done in 2008) in the United States and included lakes more than 4 hectares in surface area and 1 meter (m) or more in depth (U.S. Environmental Protection Agency, 2006), excluding the Great Lakes and coastal saline lakes. Inland saline lakes were considered as part of the target population of lakes in the United States. Site selection was designed to include a subsample of lakes that coincided with the 1972 National Lake Eutrophication Survey (U.S. Environmental Protection Agency, 2006). The EPA used the National Hydrography Dataset (U.S. Geological Survey, 2006) for site selection and to establish sampling locations. The probabilistic survey targeted the population of lakes, ponds, and reservoirs across the 48 contiguous states in the United States and details of site selection, study design, and methods are detailed in U.S. Environmental Protection Agency (2007a and 2007b).

Table 1. Provisional World Health Organization (WHO) recreational guidelines for microcystin-LR, cyanobacterial abundance, and chlorophyll-a in surface waters. ${ }^{1}$

[cells/mL, cells per milliliter; $\mu \mathrm{g} / \mathrm{L}$, micrograms per liter]

\begin{tabular}{lcccc}
\hline $\begin{array}{c}\text { Relative probability of } \\
\text { acute health effects }\end{array}$ & Numerical category & $\begin{array}{c}\text { Cyanobacteria } \\
(\mathbf{c e l l s} / \mathbf{m L})^{2}\end{array}$ & $\begin{array}{c}\text { Microcystin-LR } \\
(\boldsymbol{\mu g} / \mathbf{L})^{3}\end{array}$ & $\begin{array}{c}\text { Chlorophyll-a } \\
(\boldsymbol{\mu g} / \mathbf{L})^{4}\end{array}$ \\
\hline Low & 1 & $<20,000$ & $<10$ & $<10$ \\
Moderate & 2 & $20,000-100,000$ & $10-20$ & $10-50$ \\
High & 3 & $100,000-10,000,000$ & $20-2,000$ & $50-5,000$ \\
Very high & 4 & $>10,000,000$ & $>2,000$ & $>5,000$ \\
\hline
\end{tabular}

${ }^{1}$ Based on information presented in Chorus and Bartram, 1999. Table after Graham and others, 2009.

${ }^{2}$ The WHO guidelines were developed for Microcystis sp. dominated samples with an assumed toxin content of 0.2 picograms of microcystin per Microcystis sp. cell or 0.4 micrograms of microcystin per microgram of chlorophyll- $a$ with a minimum criteria of at least cyanobacteria dominance.

${ }^{3}$ Although the WHO guidelines are specifically for microcystin-LR, enzyme-linked immunosorbent assays (the most commonly used measure of microcystins) do not separate microcystin and nodularin congeners. Therefore, total microcystin and nodularin concentrations often are used to assess the probability of acute health effects instead of microcystin-LR concentrations.

${ }^{4}$ Chlorophyll- $a$ measurements serve as a surrogate for algal biomass and may be used singly, in the absence of additional information, or in addition to cyanobacteria abundance and microcystin measurements. 


\section{Sample Processing and Analysis of Surface-Water Samples}

Sample collection protocols for the NLA are described in U.S. Environmental Protection Agency, 2007b. Samples also were collected at four sites in Alaska that were studied as part of a pilot project for the 2007 NLA that were not previously included in the 2007 NLA report summary (U.S. Environmental Protection Agency, 2009b). Briefly, integrated photic (or euphotic) zone samples were collected from 1,161 lakes during May through October 2007. Samples typically were collected at the deepest part of each lake that crews could find based on professional estimate and 20 minutes of searching; in reservoirs, the sample site was located mid-reservoir rather than at the deepest point, which typically was located near the dam (Thornton and others, 1990). A subset of 95 lakes was resampled on alternate dates from the original sampling event; multiple samples from the same lake are herein referred to as Visit 1 and Visit 2. Visit 2 data were intended to assess temporal variation. Sequential replicate samples were collected at 75 lakes in approximately the same location during one of the visits (10 samples at first visit and 65 samples at second visit). Combined, this resulted in a total of 1,331 samples $(1,161$ lakes, 95 lakes resampled, and sequential replicates from 75 lakes) that were analyzed (See "All_ELISA_Field_Data" tab in the Excel file noted in appendix 1 for sample collection dates and table 2 for sample analysis breakdown). All samples were collected by EPA-trained field teams using a 2-m length of polyvinyl chloride pipe with an internal diameter of 3.2 centimeters $(\mathrm{cm})$ equipped with a ball valve based on a design used by the Minnesota Pollution Control Agency (M. Lindon, written commun., 2009). All equipment was triple-rinsed in the field near the designated sample collection point (U.S. Environmental Protection Agency, 2007b). Samples were integrated at depths up to $2 \mathrm{~m}$ or at two times the depth at which a Secchi disk reappeared, whichever approach provided shallower depth. Collectively, these samples will be referred to as photic zone samples throughout the remainder of this report. Multiple photic zone samples were composited into a 4 liter (L) cubitainer. Sequential replicates were collected from separate composite samples (U.S. Environmental Protection
Agency, 2007b). Samples were shipped overnight on ice or shipped overnight after freezing to the USGS Organic Geochemistry Research Laboratory in Lawrence, Kansas. In the laboratory, all samples were processed by three sequential freeze/thaw cycles to lyse cyanobacteria (Loftin and others, 2008; Graham and others, 2010; U.S. Environmental Protection Agency, 2007a). Lysed samples [10 milliliters ( $\mathrm{mL})]$ were filtered using 0.45 -micron polyvinylidene difluoride membrane syringe filters (Millex ${ }^{\circledR} \mathrm{HV}$, Millipore, Cork, Ireland) and stored frozen at -20 degrees Celsius $\left({ }^{\circ} \mathrm{C}\right)$ in $10-\mathrm{mL}$ clear glass crimp top Chromacol vials (Chromacol, Ltd., Welwyn Garden City, Herts, United Kingdom) until analysis.

\section{Analysis and Quality Control of Cyanotoxin Measurements by Enzyme-Linked Immunosorbent Assay}

The number of samples analyzed by enzyme-linked immunosorbent assay (ELISA), including field and laboratory replicates and laboratory matrix spikes are summarized in table 2. All analyses were done on a single frozen aliquot from each site after cell lysis and filtration. Field sequential replicates (abbreviated as "fr" in the "Visit Code" column of "All_ELISA_Field_Data" in appendix 1) are usually intended to assess replication of field techniques during sample collection. Although this approach can work well when samples are homogeneous, cyanobacteria blooms can be quite dynamic and heterogeneous over time and space, which can lead to poor agreement for cyanotoxin measurements (Graham and others, 2006; Sitoki and others, 2012). Therefore, variation in cyanotoxin field replicate data should not necessarily be considered an accurate assessment of sample collection techniques, but perhaps is more useful to assess how representative the sample is within a given area or as an estimate of heterogeneity with respect to cyanobacteria or toxin occurrence or both through time or space or both.

Quality control included analysis of positive and negative controls (not shown in this report), laboratory replicates, and cyanotoxin amended laboratory replicates (at equivalent concentrations: cylindrospermopsin at $1.0 \mu \mathrm{g} / \mathrm{L}$, microcystin-LR at 0.75 or $1.0 \mu \mathrm{g} / \mathrm{L}$, and saxitoxins at $0.20 \mu \mathrm{g} / \mathrm{L}$ ). Cyanotoxin

Table 2. Summary of samples analyzed by enzyme-linked immunosorbent assay.

[ELISA, enzyme-linked immunosorbant assay]

\begin{tabular}{lccccc}
\hline \multicolumn{1}{c}{ ELISA } & Visit 1 & Visit 2 & Field replicates & Laboratory replicates & Laboratory matrix spikes \\
\hline & & \multicolumn{4}{c}{ Number of samples } \\
\cline { 2 - 6 } Cylindrospermopsins & 1,161 & 95 & 75 & 290 & 189 \\
Microcystins & 1,161 & 95 & 75 & 321 & 125 \\
Saxitoxins & 1,161 & 95 & 75 & 277 & 51 \\
\hline
\end{tabular}


recovery of amended samples was calculated by using equation 1:

Percent recovery $=\left[\left(C_{\text {amended }}-C_{\text {unamended }}\right) / C_{\text {expected }}\right] \times 100$

where

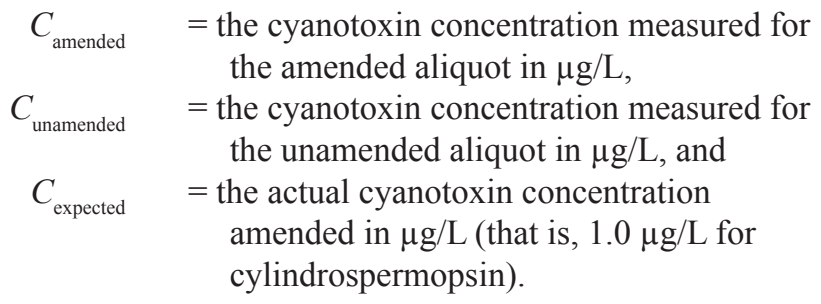

At least three positive controls were analyzed per ELISA 96-well plate. Quality-control samples for ELISA accounted for greater than 1,000 additional analyses for this work. Samples with responses greater than the upper limit of the respective calibration curve were diluted to the mid-range of the respective calibration curve with distilled/deionized water before reanalysis.

\section{Total Cylindrospermopsins Measured by Enzyme-Linked Immunosorbent Assay}

All samples were analyzed per manufacturer directions (Abraxis, LLC, 2009a) by an enzyme-linked immunosorbent assay (Abraxis, LLC, Warminster, Pennsylvania). The antibody-binding mechanism has not been published; however, cross-reactivity for this assay has been reported to include deoxycylindrospermopsin at 112 percent based on a cylindrospermopsin standard (Abraxis, LLC, 2007). No published information was available regarding whether 7-epicylindrospermopsin is detected by the antibody used in this assay. The minimum reporting level (MRL) for the assay is $0.05 \mu \mathrm{g} / \mathrm{L}$ as cylindrospermopsin equivalents.

\section{Total Microcystins/Nodularins Measured by Enzyme-Linked Immunosorbent Assay}

All samples were analyzed per manufacturer directions (Abraxis, LLC, 2007) by a polyclonal enzyme-linked immunosorbent assay (Abraxis, LLC, Warminster, Pa.). The binding mechanism of the assay is specific to the $(2 \mathrm{~S}, 3 \mathrm{~S}$, 8S, 9S)-3-amino-9-methoxy-2,6,8-trimethyl-10-phenyldeca4,6-dienoic acid moiety (ADDA) common in all microcystins and nodularins (another class of cyanobacterial hepatoxins); therefore results from this assay may include contributions from any compound with the ADDA moiety (Abraxis, LLC, 2007; Fischer and others, 2001; Chorus and Bartram, 1999). The minimum reporting level (MRL) for the assay is $0.10 \mu \mathrm{g} / \mathrm{L}$ as microcystin-LR equivalents.

\section{Total Saxitoxins Measured by Enzyme-Linked Immunosorbent Assay}

All samples were analyzed per manufacturer directions (Abraxis, LLC, 2009b) by an enzyme-linked immunosorbent assay (Abraxis, LLC, Warminster, Pa.), except that the saxitoxin freshwater sample preparation solution was not added to samples at the time of collection for preservation of saxitoxins since this was not an initial goal of the 2007 NLA. As long as samples were maintained frozen $\left(-20^{\circ} \mathrm{C}\right)$ aside from brief thaws for analysis, saxitoxin response by ELISA was determined to be stable over time. However, a brief holding time study indicated a decrease of saxitoxin ELISA response if spiked samples were stored at 7 and $25^{\circ} \mathrm{C}$ over hours (data not shown). The antibody-binding mechanism has not been published, however, cross-reactivity for this assay has been reported to include decarbamoyl saxitoxin (29 percent); gonyautoxins-2, 3, and 5B (23 percent); sulfo gonyautoxins 1 and 2 (2.0 percent); decarbamoyl gonyautoxins 2 and 3 (1.4 percent); neosaxitoxin (1.3 percent); decarbamoyl neosaxitoxin ( 0.6 percent); and gonyautoxins 1 and 4 (less than 0.2 percent) based on a saxitoxin standard (Abraxis, LLC, 2009b). The minimum reporting level (MRL) for the assay is $0.02 \mu \mathrm{g} / \mathrm{L}$ as saxitoxin equivalents.

\section{Determination of Cyanotoxins and Other Algal Toxins by Liquid Chromatography Tandem Mass Spectrometry}

A small subset of samples $(n=27)$ was measured by LC/MS/MS for fourteen cyanotoxins and algal toxins using analytical methods described in Loftin and others, 2008; and Graham and others, 2010. This method included the cyanotoxins anatoxin-a, cylindrospermopsin, deoxycylindrospermopsin, domoic acid (marine toxin produced by diatoms), lyngbyatoxin-a, seven microcystin congeners (microcystinLA, -LF, -LR, -LW, -LY, -RR, -YR), nodularin-R, and okadaic acid (marine toxin produced by dinoflaggelates). Minimum reporting levels were estimated at $0.010 \mu \mathrm{g} / \mathrm{L}$ for each toxin (signal to noise of 5 to 7 based on peak height and multiple reaction monitoring ratios of \pm 20 percent of expected). Standard addition at a $1.0 \mu \mathrm{g} / \mathrm{L}$ equivalent concentration for each cyanotoxin was used for quantitation. If results were greater than $2.5 \mu \mathrm{g} / \mathrm{L}$ for a given cyanotoxin, samples were diluted appropriately with distilled/deionized water and reanalyzed for the compound in question. Samples were selected based on microcystin detections by ELISA. Samples (5 of 27) were analyzed as laboratory duplicates by LC/MS/MS and laboratory blanks were interspersed after every standard addition sample. No analyte carryover was observed after standard addition samples. 


\section{Summary of Results}

Cyanotoxin results for cylindrospermopsins, microcystins/nodularins, and saxitoxins by ELISA and LC/MS/MS are summarized and discussed below. All data are provided in the linked appendixes of this report.

\section{Cylindrospermopsins Enzyme-Linked Immunosorbent Assay Results}

Cylindrospermopsins were detected by ELISA above the MRL of $0.05 \mu \mathrm{g} / \mathrm{L}$ in 4.0 percent of first visit samples $(n=1,161), 4.2$ percent of second visit samples $(n=95)$, and 4.0 percent overall when all visits were combined $(n=1,331$; see appendix 1 “All_ELISA_Field_Data”). Concentrations of detections ranged from 0.05 to $4.4 \mu \mathrm{g} / \mathrm{L}$ with $0.56 \mu \mathrm{g} / \mathrm{L}$ as the mean of detections (Visits 1 and 2 combined). World Health Organization (WHO) recreational guidance levels for the relative probability of adverse health impacts for cylindrospermopsins do not currently (2014) exist; therefore results were not evaluated in this manner.

\section{Microcystins/Nodularins Enzyme-Linked Immunosorbent Assay Results}

Microcystins were detected by ELISA above the MRL of $0.10 \mu \mathrm{g} / \mathrm{L}$ in 32 percent of first visit samples $(n=1,161)$, 38 percent of second visit samples $(n=95)$, and 32 percent overall when all visits were combined $(n=1,331$, appendix 1 "All_ELISA_Field_Data"). The EPA previously reported a statistical weighted treatment of microcystin first visit results of 30 percent (U.S. Environmental Protection Agency, 2009b). All microcystin summary statistics are provided as unweighted in this report. Concentrations of detections ranged from 0.10 to $230 \mu \mathrm{g} / \mathrm{L}$ with $3.0 \mu \mathrm{g} / \mathrm{L}$ as the mean of detections (visits 1 and 2 combined). Microcystin ELISA concentrations also were categorized based on the provisional World Health Organization (WHO) recreational guidance levels for the relative probability of adverse health impacts for microcystin exposure (table 1). Application of the WHO guidelines indicated that 98 to 99 percent of the individual samples were in the "Low" category, less than 2 percent in the "Moderate" and "High" categories, and 0 percent in the "Very High" category.

\section{Saxitoxins Enzyme-Linked Immunosorbent Assay Results}

Saxitoxins were detected by ELISA above the MRL of $0.02 \mu \mathrm{g} / \mathrm{L}$ in 7.6 percent of first visit samples $(n=1,161)$, 8.4 percent of second visit samples $(n=95)$, and 7.7 percent overall when all visits were combined $(n=1,331$, appendix 1 “All_ELISA_Field_Data"). Concentrations of detections ranged from 0.02 to $0.38 \mu \mathrm{g} / \mathrm{L}$ with $0.061 \mu \mathrm{g} / \mathrm{L}$ as the mean of detections (visits 1 and 2 combined). World Health Organization (WHO) recreational guidance levels for the relative probability of adverse health impacts for saxitoxins do not currently (2014) exist, therefore results were not evaluated in this manner.

\section{Toxin Analysis by Liquid Chromatography Triple Quadrupole Mass Spectrometry}

The LC/MS/MS results are shown in appendix 10 "LCMSMS" for 27 samples reanalyzed to confirm microcystin ELISA results. At least one microcystin congener was detected in 52 percent of the samples above the LC/MS/MS MRL of $0.010 \mu \mathrm{g} / \mathrm{L}$ as compared to 48 percent by microcystin ELISA in this same dataset. Additionally, anatoxin-a, cylindrospermopsin, and nodularin-R were detected in 15, 7, and 4 percent of samples, respectively.

\section{Quality-Control Data Summary}

All negative controls for ELISA had an absorbance greater than or equal to 0.8 absorbance units and all positive controls, sequential field replicates, laboratory replicates, and matrix spikes were recovered with a 28.3 percent relative standard deviation (PRSD) or less (that is, plus or minus 20 percent of expected or mean value) compared to the expected concentration. Mean PRSD values for laboratory replicates and matrix spike recovery for cylindrospermopsins ELISA were 11 percent and 99 percent, microcystins ELISA were 7.9 percent and 102 percent, and saxitoxins ELISA were 14 percent and 87 percent, respectively. Mean PRSD for sequential field replicates were 2.4 percent, 14 percent, and 5.9 percent for cylindrospermopsins, microcystins, and saxitoxins, respectively. Samples were not included in calculations of mean PRSD if at least one measurement of a set of replicate measurements was below the MRL. Five of the 27 samples also were analyzed as laboratory LC/MS/MS duplicates and had an overall mean PRSD of 9.7. 


\section{References Cited}

Abraxis, LLC, 2007, Microcystins-ADDA ELISA (Microtiter Plate), Product No. 520011, accessed May 2007, at http:// www.abraxiskits.com/wp-content/uploads/2014/08/Microcystin-PL-ADDA-Users-Guide-ETV-R082714.pdf.

Abraxis, LLC, 2009a, Cylindrospermopsin ELISA (Microtiter Plate), Product No. 522011, accessed October 2009, at http://www.abraxiskits.com/wp-content/uploads/2015/02/ Cylindrospermopsin-Insert-R021215.pdf.

Abraxis, LLC, 2009b, Saxitoxin (PSP) ELISA, Microtiter Plate, Product No. 52255B, accessed October 2009, at http://www.abraxiskits.com/wp-content/uploads/2014/04/ STXplateinsertR042414.pdf.

Abraxis, LLC, 2009c, Saxitoxin in Freshwater Sample Preparation, accessed October 2009, at http://www.abraxiskits. com/uploads/products/docfiles/53_PN52255Bprep.pdf.

Chorus, I., and Bartram, J., eds., 1999, Toxic cyanobacteria in water-A guide to their public health consequences, monitoring and management: Spon Press, London, chap. 1-5.

de la Cruz, A., Hiskia, A., Kaloudis, T., Chernoff, N., Hill, D., Antoniou, M., Loftin, K.A., O’Shea, K., Zhao, C., Pelaez, M., Han, C., Lynch, T., and Dionysiou, D., 2013, A review on cylindrospermopsin-The global occurrence, detection, toxicity and degradation of a potent cyanotoxin: Environmental Science-Processes and Impacts, no. 11, p. 1979-2003.

Etheridge, S.M., 2010, Paralytic shellfish poisoning-Seafood safety and human health perspectives: Toxicon, v. 56, p. $108-122$.

Fischer, W.J., Garthwaite, I., Miles, C.O., Ross, K.M., Aggen, J.B., Chamberlin, A.R., Towers, N.R., and Dietrich, D.R., 2001, Congener-independent immunoassay for microcystins and nodularins. Environmental Science and Technology, v. 35 , p. $4849-4856$.

Graham, J.L., Loftin, K.A., Ziegler, A.C., and Meyer, M.T., 2008 , Guidelines for design and sampling for cyanobacterial toxin and taste-and-odor studies in lakes and reservoirs: U.S. Geological Survey Scientific Investigations Report 2008-5038, 39 p.

Graham, J.L., Jones, J.R., Jones, S.B., and Clevenger, T.E., 2006, Spatial and temporal dynamics of microcystin in a Missouri reservoir: Lake and Reservoir Management, v. 22, p. 59-68.

Graham, J.L., Loftin, K.A., Kamman, N., 2009, Algal toxins-Monitoring recreational freshwaters: Lakeline, v. 29, p. 19-24.
Graham, J.L., Loftin, K.A., Meyer, M.T., and Ziegler, A.C., 2010, Cyanotoxin mixtures and taste-and-odor compounds in cyanobacterial blooms from the Midwestern United States: Environmental Science and Technology, v. 44, no. 19 , p. $7361-7368$.

Loftin, K.A., Meyer, M.T., Rubio, F., Kamp, L., Humphries, E., and Whereat, E., 2008, Comparison of two cell lysis procedures for recovery of microcystins in water samples from Silver Lake in Dover, Delaware with microcystin producing cyanobacterial accumulations: U.S. Geological Survey Open-File Report 2008-1341, 9 p.

Mazmouz, R., Chapuis-Hugon, F., Mann, S., Pichon, V., Méjean, A., and Ploux, O., 2010, Biosynthesis of cylindrospermopsin and 7-epicylindrospermopsin in Oscillatoria sp. Strain PCC 6506-Identification of the cyr gene cluster and toxin analysis: Applied and Environmental Microbiology, v. 76, p. $4943-4949$.

Merel, S., Walker, D., Chicana, R., Snyder S., Baurès, E., and Thomas, O., 2013, Review-State of knowledge and concerns on cyanobacterial blooms and cyanotoxins: Environment International, v. 59, p. 303-327.

Sitoki, L., Kurmayer, R., and Rott, E., 2012, Spatial variation of phytoplankton composition, biovolume, and resulting microcystin concentrations in the Nyanza Gulf (Lake Victoria, Kenya): Hydrobiologia, v. 691, p. 109-122.

Thornton, K.W., Kimmel, B.L., and Payne, F.E., eds., 1990, Reservoir limnology_Ecological perspectives: New York, John Wiley.

U.S. Environmental Protection Agency, 2006, Survey of the Nation's lakes: Fact Sheet-EPA 841-F-06-006. [Also available at http://www.epa.gov/owow/lakes/lakessurvey/lakessurveyfactsheet.pdf.]

U.S. Environmental Protection Agency, 2007a, Survey of the Nation's lakes: Quality Assurance Project Plan-EPA 841B-07-003, http://www.epa.gov/owow/lakes/lakessurvey/pdf/ qualityassuranceplan_draft.pdf.

U.S. Environmental Protection Agency, 2007b, Survey of the Nation's lakes, Field operations manual: EPA 841-B-07004. [Also available at http://www.epa.gov/owow/lakes/ lakessurvey/pdf/lakes_field_op_manual.pdf].

U.S. Environmental Protection Agency, 2009a, Office of Water, Office of Wetlands, Oceans, and Watersheds, Monitoring and Assessing Water Quality, National Aquatic Resources Surveys: accessed on March 13, 2009, at http:// www.epa.gov/owow/monitoring/nationalsurveys.html.

U.S. Environmental Protection Agency, 2009b, National Lakes Assessment-A collaborative survey of the Nation's lakes: EPA 841-R-09-001. 
U.S. General Accounting Office, 2000, Report to the Chairman, Subcommittee on Water Resources and Environment, Committee on Transportation and Infrastructure, House of Representatives - Water quality-Key EPA and State decisions limited by inconsistent and incomplete data: GAO, RCED-00-54.

U.S. Geological Survey, 2006, National hydrography dataset. [Also available at http://nhd.usgs.gov/index.html]. 



\section{Appendixes 1-10}

Data from the 2007 U.S. Environmental Protection Agency National Lake Assessment for total cylindrospermopsins, microcystins/nodularins, and saxitoxins enzyme-linked immunosorbent assay (ELISA) and liquid chromatography triple-quadrupole mass spectrometry (LC/MS/MS).

Electronic results have been compiled and organized into an Excel file containing 10 worksheets and are available for download at http://dx.doi.org/10.3133/ds929. Descriptions of all headings and abbreviations used in the file are contained in the "KEY TO ALL APPENDIXES" worksheet. The table below lists the name of each appendix and its description. All U.S. Environmental Protection Agency sample identification, location, and date information is maintained by U.S. Environmental Protection Agency and was downloaded from http://water.epa.gov/type/ lakes/NLA_data.cfm.

\section{List of appendixes.}

[ELISA, enzyme-linked immunosorbant assay; PRSD, percent relative standard deviation; $\mu \mathrm{g} / \mathrm{L}$, micrograms per liter; LC/MS/MS, Liquid chromatography triple quadrupole mass spectrometry]

\begin{tabular}{|c|c|}
\hline Appendix name & Description \\
\hline Key to all appendixes & $\begin{array}{l}\text { Metadata for the information contained in the } \\
\text { appendixes. }\end{array}$ \\
\hline Appendix 1.ALL_ELISA_FIELD_DATA & $\begin{array}{l}\text { Appendix } 1 \text { contains all ELISA cyanotoxin Visit } 1 \\
\text { and } 2 \text { and sequential field replicate data. }\end{array}$ \\
\hline Appendix 2. SEQ_FIELD_REPLICATES & $\begin{array}{c}\text { Appendix } 2 \text { contains all ELISA cyanotoxin } \\
\text { sequential field replicate data and PRSD. }\end{array}$ \\
\hline Appendix 3. LAB_REPLICATES_CYLINDRO & $\begin{array}{l}\text { Appendix } 3 \text { contains all ELISA cylindrospermop- } \\
\text { sin laboratory replicate data and PRSD. }\end{array}$ \\
\hline Appendix 4. LAB_REPS MC & $\begin{array}{l}\text { Appendix } 4 \text { contains all ELISA microcystin labora- } \\
\text { tory replicate data and PRSD. }\end{array}$ \\
\hline Appendix 5. LAB_REPS_SAX_0.20 & $\begin{array}{l}\text { Appendix } 5 \text { contains all ELISA saxitoxin labora- } \\
\text { tory replicate data and PRSD. }\end{array}$ \\
\hline Appendix 6. LAB_RECOVER_CYLINDRO_1.0 & $\begin{array}{l}\text { Appendix } 6 \text { contains all ELISA } 1.0 \mu \mathrm{g} / \mathrm{L} \text { cylindro- } \\
\text { spermopsin amended percent recovery and mean } \\
\text { PRSD data. }\end{array}$ \\
\hline Appendix 7. LAB_RECOVER_MC_0.75 & $\begin{array}{l}\text { Appendix } 7 \text { contains all ELISA } 0.75 \mu \mathrm{g} / \mathrm{L} \text { micro- } \\
\text { cystin amended percent recovery and mean } \\
\text { PRSD data. }\end{array}$ \\
\hline Appendix 8. LAB_RECOVER_MC_1.0 & $\begin{array}{l}\text { Appendix } 8 \text { contains all ELISA } 1.0 \mu \mathrm{g} / \mathrm{L} \text { micro- } \\
\text { cystin amended percent recovery and mean } \\
\text { PRSD data. }\end{array}$ \\
\hline Appendix 9. LAB_RECOVER_SAX_0.20 & $\begin{array}{l}\text { Appendix } 9 \text { contains all ELISA } 0.20 \mu \mathrm{g} / \mathrm{L} \text { saxitoxin } \\
\text { amended percent recovery and mean PRSD data. }\end{array}$ \\
\hline Appendix 10. LCMSMS & $\begin{array}{l}\text { Appendix } 10 \text { contains all LC/MS/MS data and } \\
\text { laboratory replicate data for } 12 \text { cyanotoxins and } \\
2 \text { algal toxins. }\end{array}$ \\
\hline
\end{tabular}


Publishing support provided by: Rolla Publishing Service Center

For additional information concerning this publication, contact: Director, USGS Kansas Water Science Center 4821 Quail Crest Place

Lawrence, KS 66049

(785) 842-9909

Or visit the Kansas Water Science Center Web site at: http://ks.water.usgs.gov 



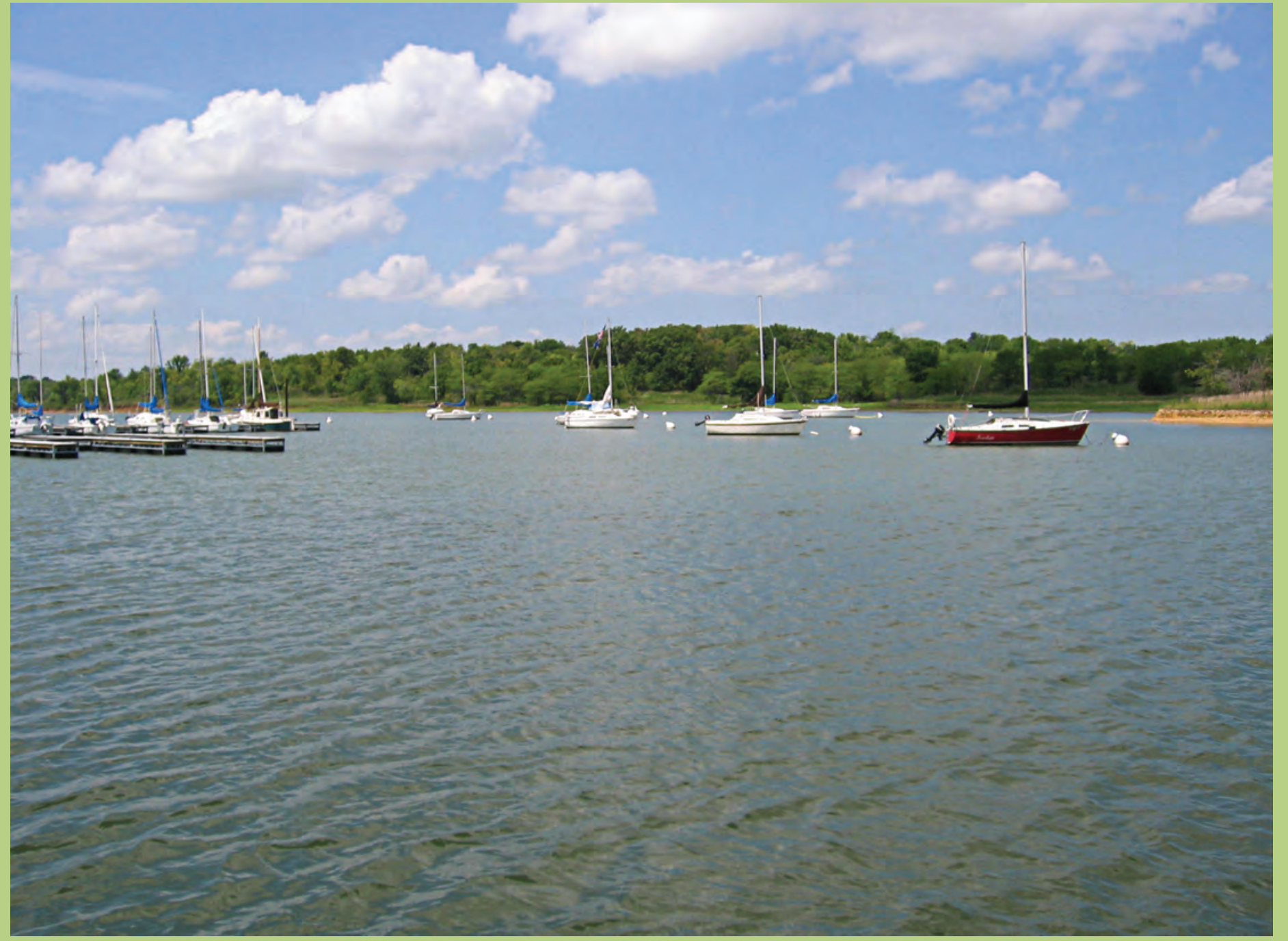

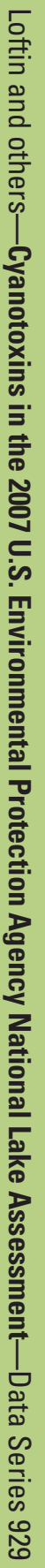

